\title{
Characterization and Classification of Agricultural Production Systems in the Galapagos Islands (Ecuador)
}

\author{
Víctor Barrera1 ${ }^{*}$, Álvaro Monteros-Altamirano ${ }^{\circledR}$, Marilú Valverde ${ }^{2}$, Luis Escudero', \\ Joanna Allauca ${ }^{2}$, Angélica Zapata ${ }^{1}$ \\ ${ }^{1}$ Estación Experimental Santa Catalina, Instituto Nacional de Investigaciones Agropecuarias (INIAP), Quito, Ecuador \\ ${ }^{2}$ Researchers at the Centro de Bioconocimiento y Desarrollo Agrario CBDA Galapagos, INIAP, San Cristobal Island, Galapagos, \\ Ecuador
}

Email: *vbarrera70@hotmail.com

How to cite this paper: Barrera, V., Monteros-Altamirano, Á., Valverde, M., Escudero, L., Allauca, J. and Zapata, A. (2021) Characterization and Classification of Agricultural Production Systems in the Galapagos Islands (Ecuador). Agricultural Sciences, 12, 481-502.

https://doi.org/10.4236/as.2021.125031

Received: April 8, 2021

Accepted: May 11, 2021

Published: May 14, 2021

Copyright (c) 2021 by author(s) and Scientific Research Publishing Inc. This work is licensed under the Creative Commons Attribution International License (CC BY 4.0).

http://creativecommons.org/licenses/by/4.0/

\begin{abstract}
The low level of agricultural productivity within the production systems in the insular region of Galapagos is caused by the lack of sustainable technologies accordingly to the insular conservation regime. As a consequence, producers face low productivity and economic losses, which result in low levels of incomes and hasten the change from agricultural to tourist activities. With consequent abandonment of productive lands, the presence of invasive species and pathogens has become a growing threat to the biodiversity of the Galapagos National Park. For this reason, it is necessary to generate and disseminate technologies adapted to the prevalent production systems in the islands. Primary data were collected through face-to-face surveys in a sample of 208 producers from 4 islands during the period from July to November 2018. Multivariate analyses (principal components and cluster) were applied to characterize and classify typical agricultural production systems. The results show three types of systems, differentiated mainly by the technology used in the management of agricultural production, that influence the yields of crops and of animal products such as beef and milk, which cannot satisfy the demand for food on the islands, which has created the dependence on imports to cover the production gap. The definition of the types of agricultural production systems can help in identifying sustainable production alternatives that integrate local social and environmental needs. This is one of the very few technical descriptions of farms on the islands and should be used by policymakers to plan interventions.
\end{abstract}




\section{Keywords}

Agricultural Productivity, Types of Systems, Biodiversity, Multivariate Analysis

\section{Introduction}

The Galapagos Archipelago of Ecuador is isolated from the American continent. To the East, the central point of the Marine Reserve is $1380 \mathrm{~km}$ from Quito and $1240 \mathrm{~km}$ from Guayaquil, the two most important cities of continental Ecuador. To the North, the closest landmass is Cocos Island, which is $750 \mathrm{~km}$ from the central point of the Marine Reserve. The Galapagos Archipelago includes 234 emerged land units (islands, islets, and rocks) inventoried by the Directorate of the Galapagos National Park, surpassing by 106 units the number of units found in previous studies [1] [2] [3].

Galapagos Island, recognized since 1959 by UNESCO as a Natural Heritage of Humanity, contains a high degree of biodiversity with significant levels of endemism in its flora and fauna. They are part of the National System of Protected Areas [3] and can be conceptualized as a particular type of Socioecological System or Socio-ecosystem [4]. Economic activities, including tourism, artisanal fishing, agriculture, and livestock, depending on the integrity of these native ecosystems and the services they generate [5].

Of the land area $(799,771 \mathrm{ha}), 96.7 \%$ is a protected area under the Galapagos National Park (PNG) and 3.3\% corresponds to areas of human settlement (urban and rural), of which 19,010 ha are land intended for agricultural activities identified as Agricultural Production Units (UPAs). In the four populated islands, there are 755 UPAs, distributed 357 in Santa Cruz, 260 in San Cristobal, 127 in Isabela, and 11 in Floreana. They are run by 568 men and 187 women [6]. According to data from the Galapagos Population and Housing Census 2015 [7], the population of Galapagos is 28,000 inhabitants, including both temporary and permanent residents in addition to the 270,000 tourists who visit the islands annually (Galapagos Tourism Observatory). Despite the fact that more than 640 vascular plants have been introduced by humans to Galapagos, $90 \%$ of them deliberately [8], few studies have been conducted on the organization, management, production, and use of these species related to food, agriculture, and livestock.

Subsistence agriculture and livestock farming have been common and permanent denominators of economic activity on the islands. Settlers introduced their plants, seeds, and animals, and produced them according to the subsistence models from their places of origin. This fact explains the range of products from the Coast, Sierra, and Amazon regions of continental Ecuador, which currently grows on the islands [8]. 
According to [9], to the low agricultural and animal productivity of the local systems which has not permitted to satisfy the population demand; for now, imports are the archipelago's largest source of food: approximately $75 \%$ of the agricultural food supply was transported from the continent in 2017, which may increase to $95 \%$ by 2037 if changes in local food policies do not occur.

To overcome this problem, since 2014 the Ministry of Agriculture and Livestock (MAG) of Ecuador has led the Bio-agricultural Plan for the Galapagos, which attempts to reduce the volume of food introduced from the continent, motivating local production based on agroecology. The plan seeks to convert agriculture to an activity co-responsible for the conservation of the islands. For this purpose, the National Institute of Agricultural Research (INIAP) was requested to contribute to raising the productivity of crops for mass consumption and promote increased self-sufficiency in the islands over the medium and long term. It was considered a priority to characterize and classify the prevalent production systems in the islands to contribute to the development of technological alternatives that are friendly to the Galapagos ecosystem. It is hoped that a Research + Technological Development + Innovation $(\mathrm{R}+\mathrm{D}+\mathrm{I})$ strategy will contribute to the development of sustainable agriculture and ecological conservation.

The classification of agricultural production systems seeks to group local systems within the livelihood strategies in which they have developed their activities [10]. In 2010, the Governing Council of the Galapagos Special Regime (CGREG) carried out the "Survey of Living Conditions of Galapagos 2009-2010", which registered demographic indicators and the main socioeconomic activities, including agriculture [8]. In 2014, the "Census of Agricultural Production Units of Galapagos" [6] was carried out, with the aim of identifying and systematizing the specific characteristics of the sector, recognizing its potential in the food security of the island population. In 2016, the Non-Governmental Organization (NGO) Conservation International (CI), in conjunction with the Galapagos Provincial Agricultural Directorate (DPAG), carried out the study "Economic Tests of the Galapagos Agricultural Sector" in Santa Cruz, with the aim of evaluating the economic situation of this sector, coming to classify the production systems according to their greatest vocation (horticultural, livestock, and coffee-growing) and according to their area (small, medium, and large) [11].

The area under study as well as the different methods to establish the sample size and the characterization and classification of the agricultural production systems of Galapagos, are described in this article. The results and discussion related to the characteristics and the grouping of the agricultural production systems are shown within the livelihood strategies to which they correspond. Our results will allow an analysis of the alternatives that these agricultural production systems provide, in order to minimize the risks of climate change, food insecurity, and increased population growth, as expressed by [9]. 


\section{Matherials and Methods}

\subsection{Description of the Study Area}

The Galapagos Archipelago (Figure 1), is located in the Pacific Ocean at the equatorial line that passes through its highest mountain, the Wolf volcano, located North of Isabela Island. The Archipelago has its geographic center at $0^{\circ} 32.22^{\prime} \mathrm{S}$ and $90^{\circ} 31.26^{\prime} \mathrm{W}$ and the Galapagos Marine Reserve has its geographic center at $0^{\circ} 05^{\prime} \mathrm{S}$ and $96^{\circ} 46^{\prime} \mathrm{W}$ [1]. The outermost reference coordinates range from $89^{\circ} 14^{\prime}$ to $92^{\circ} 00^{\prime}$ West longitude and from $1^{\circ} 40^{\prime}$ North latitude to $1^{\circ} 24^{\prime}$ South latitude, delimiting approximately an area of $133,255 \mathrm{~km}^{2}$ of land and sea (considering 40 miles of the Marine Reserve area).

A 30-year analysis of the climate in Galapagos showed an average annual rainfall of $620 \mathrm{~mm}$, distributed between the months of January to May [12]. Thanks to the existence of higher elevations in the larger islands, the humidity coming from the ocean collides with them, creating orographic precipitation. In

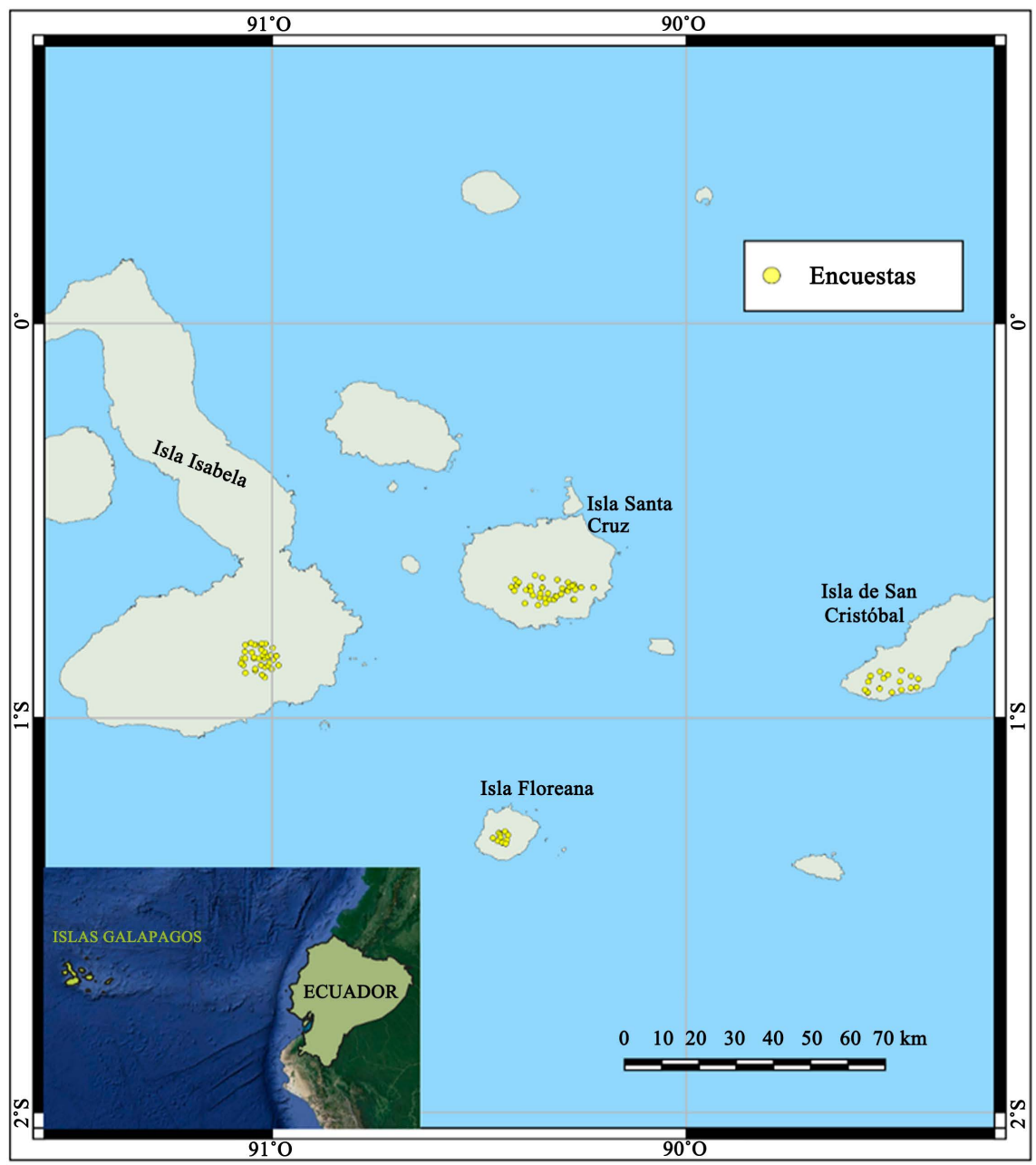

Figure 1. Location of the Galapagos-Ecuador in relation to the continent and location of the carried out surveys in Isabela, Santa Cruz, Floreana and San Cristobal Islands. Source: Barrera et al., 2019. 
this way, at higher altitudes, there is greater humidity and, therefore, greater retention of water in the soil. These are favorable conditions for the development of agriculture and livestock and the formation of surface and underground aquifers [8]. Seven islands are high enough to harbor humidity: Fernandina, Isabela, Pinta, Floreana, Santa Cruz, San Cristobal and Santiago. The upper area of these islands is characterized by high rainfall and periods of strong drizzle "garúa". These conditions allow inhabitants of the four populated islands (Isabela, Santa Cruz, San Cristobal and Floreana) to develop agro-productive activities within a humid ecosystem [8]. Figure 1 shows the four islands selected for this study.

\subsection{Sample Size Estimation}

Following a review of secondary data about agricultural production in the Galapagos, the size of the sample was determined using the continuous variable "area of agricultural production systems", based on the Census of Agricultural Production Units of Galapagos [6]. The formula used to estimate the sample size was [13]:

$$
n=\frac{\frac{t^{2}(\alpha)}{\varepsilon^{2}} \times \frac{s^{2}}{\bar{x}_{N}^{2}}}{1+\frac{1}{N} \times \frac{t^{2}(\alpha)}{\varepsilon^{2}} \times \frac{s^{2}}{\bar{x}_{N}^{2}}}
$$

where $t$ is the tabular value of Student's " $t$ " at 95\% (1.96), $\varepsilon$ is the permissible error at $5 \%(0.05), s^{2}$ is the variance of the surface of the production systems (37), $\bar{x}_{N}$ is the average area of the production systems (14.09 ha), $N$ is the number of production systems located in Galapagos (755 UPAs), reported in the Census of Agricultural Production Units of Galapagos 2014, and $n$ is the calculated sample size, which for the present study is equivalent to 208 UPAs. Therefore, a total of 208 producers from the four populated islands of Galapagos were surveyed (Table 1; Figure 1). The phases, preparatory (through preliminary field tests), data collection, and finally the processing and documentation of the information, lasted one year (2018).

Table 1. Sample distribution. Number and percentage of producers of agricultural production systems per island in Galapagos-Ecuador.

\begin{tabular}{ccc}
\hline & \multicolumn{2}{c}{ Producers } \\
\cline { 2 - 3 } Islands & $($ No. $)$ & $(\%)$ \\
\hline Floreana & 12 & 5.77 \\
Isabela & 39 & 18.75 \\
San Cristobal & 67 & 32.21 \\
Santa Cruz & 90 & 43.27 \\
Galápagos & 208 & 100.00 \\
\hline
\end{tabular}

Source: Barrera et al., 2019. 


\subsection{Characterization of Agricultural Production Systems}

The questionnaire was composed of twenty-three sections and a general data section [10]. To understand and describe the characteristics of the agricultural production systems, data on the following variables were included: Gender of heads of household in agricultural production systems (\%), $\mathrm{V}_{1}$; Age in years of the heads of households in the agricultural production systems, $V_{2}$; Number of years of formal education of heads of households in agricultural production systems, $\mathrm{V}_{3}$; Years that heads of households of agricultural production systems have lived on the islands, $\mathrm{V}_{4}$; Years dedicated to agricultural activities by heads of households of agricultural production systems, $\mathrm{V}_{5}$; Heads of households who have relief in agriculture and livestock in agricultural production systems, $\mathrm{V}_{6}$; Producers who carried out crop rotation in the lots of the agricultural production systems (\%), $\mathrm{V}_{7}$; Total area in ha of agricultural production systems, $\mathrm{V}_{8}$; Topography of agricultural production systems, $\mathrm{V}_{9}$; Current land use within agricultural production systems, and $\mathrm{V}_{10}$; and Average area in ha according to land use within agricultural production systems, $\mathrm{V}_{11}$.

The statistical analysis of the information was carried out using the Statistical Package for the Social Sciences (SPSS + 21.0) program, producing descriptive statistics such as frequencies, averages, standard deviation, minimum values, maximum values, and total values, depending on the variable under study.

\subsection{Classification of Agricultural Production Systems}

To define the groups of agricultural production systems, 21 variables were considered (Table 2), related to socioeconomic aspects, possession and use of land, livestock productivity, use of agricultural technology, pasture management, water availability and use of reservoirs, credit, migration, technical assistance and training of producers.

To define the groups of agricultural production systems, multivariate methods were used: Principal Component Analysis (PCA) and cluster analysis.

For the PCA, the selected variables were standardized in the form of Z-scores, assigning values to mean $=0$ and standard deviation $=1$ [14]. This procedure made it possible to eliminate the effects of scale and units of measurement so that each variable had the same statistical weight at the time of analysis. Standardization was carried out using the expression:

$$
Z_{i j}=\frac{x_{i j}-\mu_{j}}{\sigma_{j}}
$$

where: $Z_{i j}$ represented the individual values, $x_{i j}$ a value of the variable under analysis, and $\mu_{j}$ and $\sigma_{j}$ the mean and standard deviation $(i=1, \cdots, 208$ agricultural production systems) of the variables $(j=1, \cdots, 21)$.

For the cluster analysis, once the variables were converted into Z-scores through the PCA, 21 dimensional spaces were established where each axis represented the variables under analysis. The appropriate distance measure for 
Table 2. Variables used in the classification of agricultural production systems in Galapagos-Ecuador.

\begin{tabular}{|c|c|c|}
\hline Variables under study & $\bar{x}$ & $s$ \\
\hline $\mathrm{V}_{1}=$ Altitude $(\mathrm{msnm})$ & 305 & 124 \\
\hline $\mathrm{V}_{2}=$ People who make up the household (No.) & 3.4 & 1.7 \\
\hline $\mathrm{V}_{3}=$ Experience as an agricultural producer (years) & 24.2 & 17.1 \\
\hline $\mathrm{V}_{4}=$ Age of the head of household (years) & 56.3 & 14.1 \\
\hline $\mathrm{V}_{5}=$ Schooling of the head of household (years) & 9.1 & 5.1 \\
\hline $\mathrm{V}_{6}=$ Total property area $(\mathrm{ha})$ & 21.1 & 46.2 \\
\hline $\mathrm{V}_{7}=$ Area dedicated to agriculture (ha) & 6.2 & 14.3 \\
\hline $\mathrm{V}_{8}=$ Area dedicated to livestock (ha) & 27.8 & 35.2 \\
\hline $\mathrm{V}_{9}=$ Households that have irrigation water $(\%)$ & 76.0 & - \\
\hline$V_{10}=$ Households with enough irrigation water $(\%)$ & 5.3 & - \\
\hline $\mathrm{V}_{11}=$ Households that have water reservoirs (\%) & 83.2 & - \\
\hline $\mathrm{V}_{12}=$ Percentage of use of technology in agriculture (\%) & 32.2 & 19.9 \\
\hline $\mathrm{V}_{13}=$ Households that manage pastures (\%) & 37.0 & - \\
\hline $\mathrm{V}_{14}=$ Cows in milk production (No.) & 9.2 & 9.2 \\
\hline $\mathrm{V}_{15}=$ Male bovines $($ No. $)$ & 9.1 & 11.5 \\
\hline $\mathrm{V}_{16}=$ Milk production $\left(1\right.$ animal ${ }^{-1}$ day $\left.^{-1}\right)$ & 5.8 & 3.8 \\
\hline $\mathrm{V}_{17}=$ Total milk production $\left(1 \cdot \mathrm{day}^{-1}\right)$ & 62.7 & 86.5 \\
\hline $\mathrm{V}_{18}=$ Amount received as credit (US.\$) & 16,298 & 12,600 \\
\hline $\mathrm{V}_{19}=$ Amount received for migration (US. $\$ \cdot$ year $^{-1}$ ) & 5104 & 2682 \\
\hline $\mathrm{V}_{20}=$ Households that received technical assistance (\%) & 81.3 & - \\
\hline $\mathrm{V}_{21}=$ Households that participated in training courses (\%) & 68.8 & - \\
\hline
\end{tabular}

Source: Barrera et al., 2019. $\bar{x}=$ Average y $s=$ Standard Deviation.

this analysis was the Adjusted Euclidean Distance (DEA) [15]. Production systems were more similar when they presented low Euclidean Distance coefficients and less similar when these coefficients were high. The cluster algorithm selected was Ward's method [16].

Finally, to carry out the validation of the analysis, a Univariate Analysis of Variance (ADEVA) was used, with the mathematical model of Completely Random Design (DCA), for each of the variables selected to define the production systems, using the groups of production systems as treatments. With these analyzes, it was determined, through a statistical $\mathrm{F}$ test, if there were statistical differences at the probability level $\mathrm{P} \leq 0.01$ and $\mathrm{P} \leq 0.05$ between the arithmetic means of the types of production systems established. The model used for the analysis was the Completely Random General Linear Model [17].

\section{Results}

\subsection{Characterization of Agricultural Production Systems}

The results of the characteristics of the agricultural production systems are 
shown in Table A1. In these systems, $86.1 \%$ of the heads of household were men and $13.9 \%$ women, percentages that are similar to agrees to those presented in the Census of Agricultural Production Units of Galapagos [6], where 75.2\% men and $24.8 \%$ women were reported.

The average age of the head of household was 56 years old, with a minimum of 24 years and a maximum of 91 years. [18] report an age range for producers of San Cristobal Island between 17 and 88 years old, with an average age of the households of 53 years.

Regarding education, the heads of households received, on average, 9 years of formal education; this means that, on average, the heads of households had mainly primary education. However, the maximum value of 20 years of education indicates that a percentage of the heads of households had a university and postgraduate level. The heads of households on San Cristobal Island showed the highest level of education, with an average of 10 years, indicating they reached intermediate levels of secondary education. According to SENESCYT (Secretary of Higher Education, Science, Technology and Innovation) data, in the period between 1999 and 2015, out of 3730 high school graduates from Galapagos, only 659 obtained a third-level degree [19].

The average number of years that the heads of households of the agricultural production systems have lived in Galapagos was 42, with a minimum of 5 years and a maximum of 83 years. The heads of households on Santa Cruz Island have lived in Galapagos the fewest years and San Cristobal households have remained there the longest.

The average number of years dedicated by heads of households to agricultural activities was 24, with a minimum of one year and a maximum of 81 years. [18] report that more than $60 \%$ of the producers of San Cristobal Island exceeded 10 years of permanence. The years dedicated to agricultural production could be a relevant factor in the generation of income that would ultimately translate into progressive production systems.

Up to $74.5 \%$ of the heads of household indicated that they had generational succession after they leave agriculture and livestock, which would guarantee the sustainability of the production systems management. Of these $74.5 \%, 92.9 \%$ indicated that their children would be their successors; the values by islands are Floreana, Isabela, San Cristobal, and Santa Cruz, with 87.5\%, 89.7\%, 96.0\%, and $92.7 \%$, respectively.

On average, $46.6 \%$ of producers carried out crop rotation within the different lots that make up the agricultural production systems. Producers on Santa Cruz Island had the highest percentage of crop rotation in their plots. [20], characterizing the Galapagos production systems, determined that the typology "Associated Farmers with articulation to the market" practiced crop rotation to a greater extent-including some legumes-compared to the typologies "Farmers without articulation with the market" and "Small family farmers", who used their products in greater volume for self-consumption and/or that agriculture 
does not represent their main activity.

The surface of the agricultural production systems, on average, was 21.1 ha, with a maximum area of 470.6 ha and a minimum of 0.1 ha, both present on San Cristobal Island. Producers from the Floreana and Isabela islands reported the smallest surface area of their properties and those from San Cristobal and Santa Cruz islands the largest. The total study area was 4397.5 ha involving the 208 UPAs interviewed. According to [8], between 2000 and 2014, 112 UPAs were registered with less than one hectare; UPAs with less than 20 ha increased from 337 to 530, while those UPAs with larger areas decreased from 267 to 225, indicating fast parceling that exerts accelerated pressure on ecosystems and biodiversity in protected areas due to the demand for environmental services.

Producers reported four forms of land use in their production systems, the most relevant being agricultural crops and pastures. In terms of the area occupied by the main land uses, the highest average was a pasture with 27.8 ha, with a maximum area of 155 ha and a minimum of 0.2 ha. This agrees with [6] where the most widespread use of rural land (59\%) was destined to cultivate or naturally sprouted pastures; Santa Cruz Island showed the largest average surface area (42.7 ha) in relation to the other islands. Santa Cruz and San Cristobal islands reported the largest areas for agricultural crops.

The island systems of agricultural production presented three types of topography: undulating, flat, and brook; the most prevalent in the area is undulated and flat. On Floreana Island, $91.7 \%$ of producers indicated that the topography of their production systems was flat, while on Isabela Island, $76.9 \%$ of producers indicated that it was undulating.

Galapagos' production systems are mixed and integrated by various annual and perennial crops as well as pastures used for animal production. The yields of the 31 main crops are presented in Table A2; some of which stood out such as fruit and berry trees (coffee, beans, citrus, plantain and banana); vegetables, grains (corn, beans); and rhizomes (cassava). The livestock component includes cattle for beef, dairy and dual-purpose and other species such as pigs, poultry, horses, donkeys and mules. Within the agricultural production, at least 19 crop species were reported by the producers as the most used to guarantee the income of their households including citrus, coffee, vegetables, pineapple, cassava, banana, corn, pepper and grass. Pineapple on Floreana Island and pastures in Isabela and Santa Cruz were the species that most guaranteed income according to producers. In [20], only seven crops were reported as important in generating income: coffee, citrus, pineapple, vegetables such as tomato, pepper, cucumber, and grasses, while [18] reported 44 traditional crops present in the production systems on San Cristobal Island, which shows the availability of additional species that could be integrated into the local agricultural and food systems.

\subsection{Classification of Agricultural Production Systems}

The results of the PCA for Galapagos are shown in Table 3, which include: 
Table 3. Eigenvalue, simple variance and accumulated variance explained by the factors found in the Principal Components Analysis for the agricultural production systems in Galapagos-Ecuador.

\begin{tabular}{cccc}
\hline \multirow{2}{*}{ Component } & Eigen value (Weight) & \multicolumn{2}{c}{ Variance (\%) } \\
\cline { 3 - 4 } & & Simple & Accumulated \\
\hline 2 & 4.67 & 22.25 & 22.25 \\
3 & 2.44 & 11.62 & 33.86 \\
4 & 1.96 & 9.33 & 43.20 \\
5 & 1.64 & 7.81 & 51.00 \\
6 & 1.23 & 5.86 & 56.86 \\
7 & 1.17 & 5.56 & 62.41 \\
\hline
\end{tabular}

Source: Barrera et al., 2019.

eigenvalue, simple variance and cumulative variance. The eigenvalue indicates the variance contributed by each factor or component. Simple variance is the relative weight of each factor in the total variance. The cumulative variance indicates the amount of variance explained by the factors $n+(n-1)$. According to the multivariate variance (that is, the relative weight of each factor or component in which the related variables were concentrated), the 21 variables under study were reduced to 7 main factors or components, which represented $67.64 \%$ of the cumulative variance.

Regarding the Principal Component Analysis, component 1 (Table A3) presented the highest weight with a value of 4.67 (Table 3). This value was related to animal production of both dairy and beef cattle, where the following variables were correlated: $\mathrm{V}_{6}$ (Total area of the property in ha), $\mathrm{V}_{8}$ (Area dedicated to livestock in ha), $\mathrm{V}_{13}$ (Households that manage pastures in \%), $\mathrm{V}_{14}$ (Cows in milk production in No.), $\mathrm{V}_{15}$ (Male bovines in No.), $\mathrm{V}_{16}$ (Milk production in 1 ani$\mathrm{mal}^{-1}$ day $^{-1}$ ) and $\mathrm{V}_{17}$ (Total milk production in $1 \cdot$ day $^{-1}$ ). Component 2, with a value of 2.44, was related to agricultural production, where the following variables were correlated: $\mathrm{V}_{9}$ (Households with irrigation water in \%), $\mathrm{V}_{10}$ (Households with enough irrigation water in \%), $\mathrm{V}_{11}$ (Households that have water reservoirs in \%) and $\mathrm{V}_{12}$ (Percentage of use of technology in agriculture in \%).

The number and denomination of the groups of the agricultural production systems prevalent for the islands under study in Galapagos are included in Table 4. To obtain the groups, the new variables or factors found with the PCA (Table A2) were used, while for the denomination of the groups, the most relevant of the 21 variables were taken into account (Table A4).

Group 1: Production systems with intermediate area dedicated to agriculture and livestock, with low technology in agriculture, and less technical assistance and training. 
Table 4. Groups of agricultural production systems in Galapagos-Ecuador.

\begin{tabular}{|c|c|c|c|}
\hline \multirow{2}{*}{ Galapagos/Islands } & \multicolumn{3}{|c|}{ Production system groups (number and percentage) } \\
\hline & $1(39 ; 18.75 \%)$ & $2(49 ; 23.56 \%)$ & $3(120 ; 57.69 \%)$ \\
\hline Galapagos & $\begin{array}{l}\text { Production systems } \\
\text { with intermediate } \\
\text { area dedicated to } \\
\text { agriculture and } \\
\text { livestock, with low } \\
\text { technology in } \\
\text { agriculture, and less } \\
\text { technical assistance } \\
\text { and training. }\end{array}$ & $\begin{array}{l}\text { Production systems } \\
\text { with less area } \\
\text { dedicated to } \\
\text { agriculture and } \\
\text { livestock, with } \\
\text { medium technology in } \\
\text { agriculture, and greater } \\
\text { technical assistance } \\
\text { and training. }\end{array}$ & $\begin{array}{l}\text { Production systems } \\
\text { with a larger area } \\
\text { dedicated to } \\
\text { agriculture and } \\
\text { livestock, with low } \\
\text { technology in } \\
\text { agriculture, and } \\
\text { intermediate technical } \\
\text { assistance and training. }\end{array}$ \\
\hline Floreana & $1(0 ; 0 \%)$ & $2(2 ; 16.67 \%)$ & $3(10 ; 83.33 \%)$ \\
\hline Isabela & $1(3 ; 7.69 \%)$ & $2(7 ; 17.95 \%)$ & $3(29 ; 74.36 \%)$ \\
\hline San Cristobal & $1(16 ; 23.88 \%)$ & $2(8 ; 11.94 \%)$ & $3(43 ; 64.18 \%)$ \\
\hline Santa Cruz & $1(20 ; 22.22 \%)$ & $2(32 ; 35.56 \%)$ & $3(38 ; 42.22 \%)$ \\
\hline
\end{tabular}

Source: Barrera et al., 2019.

As observed in Table 4, 18.75\% of the Galapagos agricultural production systems belong to Group 1, characterized by having an average of 2.6 people as family members. This group prioritizes the participation of heads of household as those responsible for managing production systems, whose average age is 58.8 years, an educational level of 9.7 years, and 22.7 years of experience as agricultural producers. The total area of these systems is, on average, 12.3 ha, with an area dedicated to agriculture of 3.9 ha and an area dedicated to livestock of 20.9 ha. The averages obtained for the areas of agriculture and livestock, independently, correspond to those that actually had the production systems; for example, there were production systems that only had agriculture while others only had livestock; that is why, in this group, the area dedicated to livestock was higher than the total area; $2.6 \%$ of production systems had water for irrigation, which determined that most of the crop production is carried out with rainwater. However, $43.6 \%$ of the production systems had a water reservoir that was generally supplied by rainwater and water-tanker trucks. The percentage of use of technology to manage crops, in this group, was $23.1 \%$, considered as low technology, since they barely used between one and two technological practices in their crops; while $30.8 \%$ managed pastures in a conventional way and with the application of some technology. Regarding livestock production, there were on average: 8.7 male bovines and 5.8 cows in production, 4.2 liters of milk production per animal per day and a total of 26.2 liters per day. The amounts of credit requested from financial institutions averaged 14,906 US dollars, which was mainly used for agricultural production. In addition to this, from migrant remittances they received an average of US $\$ 4050$ per year. Note that $59.0 \%$ of the production systems received technical assistance from the Ministry of Agriculture and Livestock, and $56.4 \%$ participated in training courses, where they 
learned mainly about crop management and livestock production.

Group 2: Production systems with a smaller area dedicated to agriculture and livestock, with medium technology in agriculture, and greater technical assistance and training.

This group holds $23.6 \%$ of the agricultural production systems (Table 4), characterized by having an average of 4.2 family members. In this group, heads of the household are those responsible for the management of the production systems, whose average age is 51.6 years, with an educational level of 8.5 years and 18.7 years of experience as agricultural producers. The total area owned by a household average 5.1 ha, with an area dedicated to agriculture of 3.7 ha and an area dedicated to livestock of 8.6 ha (similar to group 1). A high percentage of households in this group have water for irrigation (85.7\%); However only $8.2 \%$ of households have enough water, being forced to maintain dryland farming; 93.9\% of these production systems have a water reservoir that is generally supplied by rainwater and water-tanker trucks. The percentage of use of technology in agriculture in this group is $48.0 \%$, considered as medium technology, since they use between three and four technological practices in their crops, while only $6.1 \%$ of production systems manage pastures using some driving technology. The livestock production of this group is composed of a male bovine and two cows in production on average, which produce 16.5 liters of milk production per day. Although this group is not related to dairy and beef farming, it obtains the best average milk per animal per day ( 8.5 liters), possibly influenced by the average reported between the cows with the highest and lowest production. The amount of credit that the production systems of this group requested from financial institutions is US $\$ 13,091$ (average), destined mainly for agricultural production. In this group, on average, US $\$ 2916$ per year comes from remittances. It is important to note that $100 \%$ of the production systems of this group received technical assistance from the Ministry of Agriculture and Livestock, mainly. In addition, $95.9 \%$ of the production systems participated in training courses, where they learned mainly, crop management, marketing and livestock production.

Group 3: Production systems with a larger area dedicated to agriculture and livestock, with low technology in agriculture, and intermediate technical assistance and training.

This group contains the highest percentage of agricultural production systems with $57.7 \%$ (Table 4 ) and has 3.3 as an average number of family members. As in the previous two, the heads of household are those responsible for the management of the production systems, presenting an average age of 57.3 years, with an educational level of 9.1 years and 27.0 years of experience as agricultural producers. The total area averaged $30.6 \mathrm{ha}$, with an area dedicated to agriculture of 8.2 ha and to livestock of 30.9 ha (analysis similar to groups 1 and 2). A high percentage of production systems in this group have water for irrigation (95.8\%); however, only $5.8 \%$ of the production systems have enough water for 
irrigation, promoting dryland agriculture with a diversity of species growing only in the rainy season; $91.7 \%$ of the production systems have a water reservoir that is generally supplied by rainwater and water-tanker trucks. The percentage of use of technology for crop management is $28.8 \%$, considered low, since they use between one and two technological practices in their crops, while more than half of the production systems (51.7\%) manage pastures with the use of some technology. In relation to livestock production, this group has an average of 9.5 male bovines and 10.1 cows in production, and presents a milk production per day of 69.7 liters, with an average milk production per animal per day of $6.1 \mathrm{li}$ ters. The amounts of credit requested from financial institutions amounted to 18,298 US dollars on average, mainly destined for agricultural production. These production systems received from migrant remittances, on average, US \$ 5746 per year. $80.8 \%$ of the production systems received technical assistance from the Ministry of Agriculture and Livestock, mainly. 61.7\% of the production systems participated in training courses where they learned mainly crop management, marketing and livestock production.

\section{Discussion}

\subsection{Characterization of Agricultural Production Systems}

The islands under study together include at least 19,010 hectares destined for agricultural activities, on which they develop their agricultural and livestock production systems [8]. The family nucleus of the producers had an average size of 3.4 people, with each of them contributing to the improvement and maintenance of the production systems. Most of these people are permanent residents of the islands. $17.8 \%$ of the people in the households leave the islands for different reasons, mainly for work, study, family or health reasons. The average age of the producers who are heads of households in the production systems was 56 years and they report 9 years of studies or education. The age of the head of household and the years of study could be relevant factors in the adoption of new agricultural practices, since the waiting time between investment and economic returns from the use of new technologies is medium to long term. Studies such as [21] show greater success in adoption of new technologies the higher the education level of the producer.

The production systems of the islands were characterized by being family owned in $88.0 \%$ of the cases, which means that agricultural producers can make use of their resources in the long run to produce food, which improves the chances of food security on the islands. These agricultural systems have areas that average $21.2 \mathrm{ha}$, which constitutes an adequate space for their revitalization and intensification, without necessarily implying a greater use of inputs, but areas that could become a significant source of employment for the families that depend on them. Within the production systems, not all the land was used; of the 4397.5 reported by the producers, $25.9 \%$ were dedicated to agriculture, $59.4 \%$ to pastures, $5.5 \%$ to native trees and $9.2 \%$ rest uncultivated lands. It is 
important to note that according to [8], the land area occupied by pastures was $59 \%$ of the total area of production systems, which means that the area for pasture has increased by only $0.4 \%$.

An important aspect of the production systems was the interaction between the agricultural and livestock components, which is probably not sufficiently understood or adequately used to constitute strength in the management of plant health and/or fertility and conservation of natural resources. In this sense, it seems possible that the production systems could improve from use of elementary practices such as crop rotation, increase of the agrobiodiversity conserved and used in the production systems, positive selection of seeds, incorporation of legumes and trees, and nutrients recycling which will promote the strengthening of the resilient agricultural systems of Galapagos.

[9] and [22] identify the negative influence of the tourism industry on the local agriculture of the Galapagos Islands; for example, currently the food supply system depends $75 \%$ on agricultural products imported from the continent, weakening local agriculture. Although the population and the average food consumption have increased on the island, local agricultural production per capita has decreased, which could deepen if there are no policy changes that promote agriculture in Galapagos. Furthermore, there is a disconnect between producers and local market dynamics. Only the production of beef and pork, whose importation has been prohibited for sanitary reasons, has influenced the growth of the livestock production system in the islands [9]. This growth is evidenced in this study as grasses occupy most of the agricultural systems studied here. Poultry production could possibly satisfy local needs and prevent the importation of this product from the continent in the future.

Within the island production systems, the deterioration process of natural resources has accelerated, especially water and soil resources [23] due to intensive processes of land use, inadequate agricultural and livestock practices, and deforestation, adding to adverse climatic conditions with increasingly negative effects due to the loss of biological diversity and less presence of native or endemic species.

The decrease in native vegetation caused by the increase in the agricultural frontier and by livestock activities is evident in the areas of human intervention. There are agricultural areas that, due to the disuse they currently experience, exhibit proliferation of blackberry (Rubus niveous), guayaba (Psidium guajava), and supirosa (Lantana camara), among others [24], which deteriorate the agriculture on the islands. Few remnants of native vegetation remain. Endemic species currently existing on the islands have different levels of threat.

Data obtained from the producers and their families in this study showed there is interest in undertaking actions that favor the conservation of biodiversity, the recovery of the remnants of vegetation and the protection of water sources for both, production systems and for the preservation of the islands' biodiversity. Producers use several species of plants and trees for the benefit of 
the production systems and the people of their households; for example, 68.3\% used medicinal plants, $43.3 \%$ used introduced timber trees, $22.1 \%$ native timber trees, and $4.8 \%$ native plants.

A relevant concern from heads of households in agricultural production systems is that local agricultural production cannot satisfy the demand for food on the islands due to the attraction of labor from agriculture to the tourism industry. This livelihood transition has reduced productivity rates and created dependence on imports to fill the production gap [9].

\subsection{Of the Classification of Agricultural Production Systems}

The multivariate analysis separates clusters from agricultural production systems and thus allows characterization of livelihood strategies. The variables used to separate the groups of households were the most suitable since they represented $67.64 \%$ of the multivariate variance. Variables related to area, agricultural and livestock production, crop technology, technical assistance, training, water availability and irrigation infrastructure were the ones that had the greatest influence on the definition of the groups, but above all, the technology used in agriculture and livestock, since within each group the producers were in charge of applying or not technology in the management of agricultural production systems; a choice that undoubtedly influenced the yield in crops and in the production of beef or dairy.

Three groups of agricultural production systems at the Galapagos level were established to determine their livelihood strategies and well-being. The agricultural production systems had different total areas and areas dedicated to agriculture and livestock, where the largest area dedicated to livestock was also used for the production of dairy and beef. The production systems reported different averages of production per unit area, as well as in terms of yields in $\mathrm{kg} \cdot \mathrm{ha}^{-1} \cdot \mathrm{year}^{-1}$ and in 1 animal $^{-1}$ day $^{-1}$.

The definition of the groups of agricultural production systems with their differentiated livelihood strategies will be the basis for the economic optimization of the mechanisms that can generate better socio-economic and environmental benefits in the Galapagos Islands. If this does not happen, producers in the three groups of production systems will continue to abandon their agricultural lands due to environmental and economic constraints, as well as their involvement in alternative livelihoods such as tourism and other more lucrative economic enterprises as mentioned by [9].

Currently, the economy related to tourism in Galapagos determines that profits are mainly directed out of the islands, e.g. airlines and tourism agencies that often do not have local headquarters; therefore, tourism leaves only remnants of income to reinvest in the local economy or in the conservation of local ecosystem. In an economic study in San Cristobal, Santa Cruz and Isabela from [22], it was identified that all types of analysis for the growth of the local economy is based on tourism; however, the participation of local beneficiaries must be 
sought to complement the growth of other local activities including agricultural and livestock activities that can benefit both tourists and residents. This is supported by [25], who, through econometric simulations, determined that with the appropriate connections, ecotourism can support the growth of the agricultural and fishing sector, achieving income increments for those involved. Finally, support for local agriculture would decrease imported products, which unfortunately, can bring external elements to the islands such as pests or new invasive plant species [9] [26].

\section{Conclusions}

At present, island agricultural production does not operate at a level of efficiency that will allow for the islands' food security and sovereignty, resulting in a high dependence on food and productive inputs imported from the mainland. Additionally, the high imported commodity volumes facilitate the introduction of pests and invasive species that threaten the productive and economic viability of agriculture, and the conservation of the delicate ecosystem of the islands. Furthermore, the presence of imported products, with artificially competitive prices, stifles the market and weakens the profitability of local production.

On the one hand, there is an accelerated growth of the resident population $(28,000)$ and the number of tourists who visit the islands annually $(270,000)$. On the other, changes in land use reveal a partition of land destined for agriculture and livestock. This situation has caused an increase in the number of UPAs, which suggests a considerable division of land and a decrease in the size of the UPAs. Indeed, the number of smaller UPAs increased in contrast to the decrease in the number of larger UPAs. From 2000 to 2014, the UPAs with less than 20 ha of the surface increased from 337 to 530, while those with a larger surface went from 267 to 225; accelerating pressure on ecosystems and biodiversity in protected areas due to the demand for environmental services.

Given the importance of the Galapagos in the world panorama of ecosystem conservation, the integration of national and international, public and private institutions is vital, both for the dissemination of technologies and for the promotion of conservation agriculture. Some institutions could even support the execution and financing of sustainable agricultural research and development projects. The benefits of promoting more ecologically balanced agriculture within the Galapagos territory by promoting multidisciplinary and inter-institutional synergies are multiple: 1) the recognition of agricultural and livestock activities towards the sustainable development of the islands will increase options for receiving national and international financing; 2 ) the strengthening of agricultural production systems favoring the households involvement and the protection of the natural capital of the Galapagos; 3) the promotion of public policies to support the agricultural sector; 4) encouraging production systems that contribute to maintaining a better phytosanitary status of the island ecosystems; 5) achieving inclusive production systems with a greater capacity to generate resilience. 


\section{Acknowledgements}

To the technicians of the Ministry of Agriculture and Livestock of the Galapagos Islands who supported the gathering of the information. To Dr. George Norton for reviewing this manuscript and provide opportune advice.

\section{Conflicts of Interest}

The authors declare no conflicts of interest regarding the publication of this paper.

\section{References}

[1] Snell, H., Stone, P. and Snell, L. (1996) A Summary of Geographic Characteristics of the Galápagos Islands. Journal of Biogeography, 23, 619-624. https://doi.org/10.1111/j.1365-2699.1996.tb00022.x

[2] Tye, A., Soria, M. and Gardener, M. (2002) A Strategy for Galápagos Weeds. IUCN, Gland, 336-341.

[3] DPNG (2014) Plan de Manejo de las Áreas Protegidas de Galápagos para el Buen Vivir. Dirección del Parque Nacional Galápagos. Puerto Ayora, Galápagos-Ecuador.

[4] González, J., Montes, C., Rodríguez, J. and Tapia, W. (2008) Rethinking the Galapagos Islands as a Complex Social-Ecological System: Implications for Conservation and Management. Ecology and Society, 13, 13.

https://www.ecologyandsociety.org/vol13/iss2/art13 https://doi.org/10.5751/ES-02557-130213

[5] Tapia, W., Ospina, P., Quiroga, D., González, D. and Montes, C. (2009) Ciencias para la Sostenibilidad en Galápagos. El papel de la investigación científica y tecnológica en el pasado, presente y futuro del archipiélago. Parque Nacional Galápagos. Universidad Andina Simón Bolívar, Universidad Autónoma de Madrid y Universidad San Francisco de Quito.

[6] CGREG (2014) Censo de Unidades de Producción Agropecuaria de Galápagos. Consejo de Gobierno del Régimen Especial de Galápagos. Puerto Baquerizo Moreno, Galápagos-Ecuador. 138 p.

[7] INEC (2015) Censo de Población y Vivienda de Galápagos. http://www.ecuadorencifras.gob.ec/galapagos-tiene-25-244-habitantes-segun-censo $\underline{-2015}$

[8] CGREG (2016) Plan de Desarrollo Sustentable y Ordenamiento Territorial del Régimen Especial de Galápagos-Plan Galápagos 2015-2020. Consejo de Gobierno del Régimen Especial de Galápagos. Puerto Baquerizo Moreno, Galápagos-Ecuador. 80-105.

[9] Sampedro, C., Pizzitutti, F., Quiroga, D., Walsh, S. and Mena, C. (2020) Food Supply System Dynamics in the Galapagos Islands: Agriculture, Livestock and Imports. Renewable Agriculture and Food Systems, 35, 234-248. https://doi.org/10.1017/S1742170518000534

[10] Barrera, V., Valverde, M., Escudero, L. and Allauca, J. (2019) Productividad y sostenibilidad de los sistemas de producción agropecuaria de las islas GalápagosEcuador. Libro Técnico No. 174, ARCOIRIS Producción Gráfica, Quito, 228 p.

[11] Viteri, C. and Vergara, L. (2017) Ensayos Económicos del Sector Agrícola de Galápagos. Conservación Internacional Ecuador y Ministerio de Agricultura, Ganadería, Acuacultura y Pesca. Santa Cruz, Galápagos, 106 p.

[12] Meteoblue (2019) Clima islas Galápagos. 
https://www.meteoblue.com/es/tiempo/pronostico/modelclimate/islas-gal\%C3\%A1 pagos_ecuador_3658931

[13] Sukhatme, P. (1953) Teoría de encuestas por muestreo con aplicaciones. Traducido al español por Flores A. y Nilto J. 43.

[14] Romesburg, C. (1990) Cluster Analysis for Researchers. Robert E Kieger Publishing Company, Malabar.

[15] Everitt, B. (1993) Cluster Analysis. Third Edition, Edward Arnold a Division of Hodder \& Stoughton, New York.

[16] Ward, H. (1963) Hierarchical Grouping to Optimize and Objective Function. Journal of the American Statistical Association, 58, 236-244. https://doi.org/10.1080/01621459.1963.10500845

[17] Steel, R. and Torrie, J. (1960) Principles and Procedures of Statistics. McGraw, New York.

[18] Allauca, J., Valverde, M. and Tapia, C. (2018) Conocimiento, manejo y uso de la agrobiodiversidad en la isla San Cristobal. INIAP. Boletín Técnico 173. INDIGO 480 Publicaciones. Puerto Baquerizo Moreno, Galápagos-Ecuador. 76 p.

[19] SENPLADES (2017) Plan Nacional para el Buen Vivir 2017-2021. Secretaría Nacional de Planificación y Desarrollo (Online). Plan Nacional de Desarrollo 2017-2021, Quito. https://www.planificacion.gob.ec/wp-content/uploads/downloads/2017/10/PNBV-2 6-OCT-FINAL_0K.compressed1.pdf

[20] Chiriboga, R., Maignan, S. and Fonseca, B. (2006) Producto dos: Caracterización de los sistemas de producción en Galápagos en relación con el fenómeno de las Especies Invasoras. Desarrollo de políticas y estrategias de manejo del sector Agropecuario y su relación con las especies introducidas en la Provincia de Galápagos. Proyecto ECU/00/G31 "Especies Invasoras de las Galápagos”. Puerto Ayora, Galápagos-Ecuador.

[21] Pannell, D., Marshall, G., Barr, N., Curtis, A., Vanclay, F. and Wilkinson, R. (2006) Understanding and Promoting Adoption of Conservation Practices by Rural Landholders. Australian Journal of Experimental Agriculture, 46, 1407-1424. https://doi.org/10.1071/EA05037

[22] Taylor, J., Dyer, G., Stewart, M., Yunez-Naude, A. and Ardila, S. (2003) The Economics of Ecotourism: A Galápagos Islands Economy-Wide Perspective. Economic Development and Cultural Change. University of Chicago, Chicago, 977-997. https://doi.org/10.1086/377065

[23] Gerzabek, M., Bajraktarevic, A., Keiblinger, K., Mentler, A., et al. (2019) Agriculture Changes Soil Properties on the Galápagos Islands-Two Case Studies. Soil Research, 57, 201-214. https://doi.org/10.1071/SR18331

[24] Mauchamp, A. (1997) Threats from Alien Plant Species in the Galápagos Islands. Conservation Biology, 11, 260-263. https://doi.org/10.1046/j.1523-1739.1997.95356.x

[25] Taylor, J. and Filipski, M. (2014) Galápagos. The Myth of Ecotourism. In: Taylor, J.E. and Filipski, M.J., Eds., Beyond Experiments in Development Economics: Local Economy- Wide Impact Evaluation, The University of Chicago, Chicago, 977-997. https://doi.org/10.1093/acprof:oso/9780198707875.001.0001

[26] Kaiser, J. (2001) Galápagos Takes Aim at Alien Invaders. Science, New Series, 293, 590-592. https://doi.org/10.1126/science.293.5530.590 


\section{Annex}

Table A1. Characteristics of agricultural production systems in Galapagos-Ecuador.

\begin{tabular}{|c|c|c|c|c|}
\hline \multirow{2}{*}{ Variables } & \multicolumn{4}{|c|}{ Galapagos } \\
\hline & Men & Women & & \\
\hline \multirow{2}{*}{$\begin{array}{l}\text { Gender of heads of household in } \\
\text { agricultural production systems (\%) }\end{array}$} & 86.1 & 13.9 & & \\
\hline & Min. & Max. & Average & \\
\hline \multirow[t]{2}{*}{$\begin{array}{l}\text { Age in years of heads of households in } \\
\text { agricultural production systems }\end{array}$} & 24 & 91 & 56 & \\
\hline & Min. & Max. & Average & \\
\hline \multirow{2}{*}{$\begin{array}{l}\text { Number of years of formal education of } \\
\text { heads of households in agricultural } \\
\text { production systems }\end{array}$} & 0 & 20 & 9 & \\
\hline & Min. & Max. & Average & \\
\hline \multirow{2}{*}{$\begin{array}{l}\text { Years that the heads of households of the } \\
\text { agricultural production systems have } \\
\text { lived on the islands }\end{array}$} & 5 & 83 & 42 & \\
\hline & Min. & Max. & Average & \\
\hline \multirow{2}{*}{$\begin{array}{l}\text { Years that the heads of households of } \\
\text { agricultural production systems are } \\
\text { dedicated to agricultural activities }\end{array}$} & 1 & 70 & 24. & \\
\hline & Relief & No Relief & & \\
\hline \multirow{2}{*}{$\begin{array}{l}\text { Heads of households who have relief in } \\
\text { agriculture and livestock in agricultural } \\
\text { production systems }\end{array}$} & 74.5 & 25.5 & & \\
\hline & Yes & No & & \\
\hline \multirow{2}{*}{$\begin{array}{l}\text { Producers who carried out crop rotation } \\
\text { in the lots of the agricultural production } \\
\text { systems (\%) }\end{array}$} & 46.6 & 53.4 & & \\
\hline & Min. & Max. & Average & \\
\hline \multirow[t]{2}{*}{$\begin{array}{l}\text { Total area in ha of agricultural } \\
\text { production systems }\end{array}$} & 0.1 & 470.6 & 21.1 & \\
\hline & Crops & Pastures & $\begin{array}{l}\text { Native } \\
\text { plants }\end{array}$ & $\begin{array}{l}\text { Rest } \\
\text { uncultivated } \\
\text { land }\end{array}$ \\
\hline \multirow[t]{2}{*}{$\begin{array}{l}\text { Current land use within agricultural } \\
\text { production systems. (\% producers) }\end{array}$} & 88.0 & 45.2 & 13.0 & 9.1 \\
\hline & Crops & Pastures & $\begin{array}{l}\text { Native } \\
\text { plants }\end{array}$ & $\begin{array}{l}\text { Rest } \\
\text { uncultivated } \\
\text { land }\end{array}$ \\
\hline \multirow[t]{2}{*}{$\begin{array}{l}\text { Average area in ha according to land use } \\
\text { within agricultural production systems }\end{array}$} & 6.2 & 27.8 & 8.9 & 21.2 \\
\hline & Undulated & Flat & Brook & \\
\hline $\begin{array}{l}\text { Topography of agricultural production } \\
\text { systems }\end{array}$ & 49.5 & 46.6 & 3.9 & \\
\hline
\end{tabular}

Source: Barrera et al., 2019. 
Table A2. Yield in kilograms per hectare of crops harvested in agricultural production systems. Galapagos-Ecuador, 2019.

\begin{tabular}{|c|c|c|c|c|c|}
\hline Crop & No. & $\bar{x}$ & $s$ & Minimum & Maximum \\
\hline Chard & 6 & 5931 & 91 & 5800 & 6000 \\
\hline Avocado & 6 & 4283 & 306 & 3800 & 4500 \\
\hline Babaco & 4 & 7400 & 516 & 6800 & 8000 \\
\hline Broccoli & 10 & 5347 & 302 & 4800 & 6000 \\
\hline Sugar cane & 11 & 76,473 & 666 & 75,000 & 77,273 \\
\hline Coffee & 26 & 1050 & 51 & 1000 & 1230 \\
\hline Custard apple & 1 & 3000 & - & 3000 & 3000 \\
\hline Cilantro & 7 & 7123 & 98 & 7000 & 7200 \\
\hline Cabbage & 8 & 6216 & 185 & 6000 & 6400 \\
\hline Beans & 28 & 1938 & 132 & 1667 & 2250 \\
\hline Guaba & 11 & 2592 & 319 & 2000 & 3000 \\
\hline Soursop & 1 & 3600 & - & 3600 & 3600 \\
\hline Guineo & 55 & 10,022 & 474 & 9000 & 11,000 \\
\hline Lettuce & 13 & 5973 & 216 & 5600 & 6400 \\
\hline Lemon Meyer & 16 & 9183 & 162 & 9000 & 9600 \\
\hline Dried corn & 19 & 3812 & 365 & 3200 & 4260 \\
\hline Hominy corn & 38 & 9835 & 441 & 9045 & 11,000 \\
\hline Tangerine & 11 & 11,350 & 354 & 11,000 & 12,000 \\
\hline Mango & 3 & 7000 & 200 & 6800 & 7200 \\
\hline Melon & 4 & 3625 & 171 & 3400 & 3800 \\
\hline Orange & 44 & 10,011 & 487 & 9000 & 11,200 \\
\hline Potato & 8 & 11,239 & 685 & 10,400 & 12,000 \\
\hline Papaya & 23 & 14,676 & 417 & 14,000 & 15,300 \\
\hline Pineapple & 46 & 14,603 & 441 & 14,000 & 15,500 \\
\hline Pepper & 22 & 6578 & 533 & 6000 & 7556 \\
\hline Plantain & 88 & 9239 & 455 & 8500 & 10,000 \\
\hline Water melon & 6 & 8175 & 141 & 8000 & 8300 \\
\hline Tomato & 38 & 14,610 & 347 & 14,000 & 15,000 \\
\hline Green bean & 14 & 4794 & 309 & 4000 & 5000 \\
\hline Cassava & 82 & 14,150 & 434 & 13,500 & 15,200 \\
\hline Sapodilla & 1 & 4800 & - & 4800 & 4800 \\
\hline Galapagos & 650 & 10,643 & 9563 & 1000 & 77,273 \\
\hline
\end{tabular}

Source: Barrera et al., 2019. No. = Number of lots; $\bar{x}=$ Average; $s=$ Standard deviation. 
Table A3. Matrix of principal components or factors extracted from the 21 variables that were selected as relevant to define the groups of agricultural production systems in Galapagos-Ecuador.

\begin{tabular}{|c|c|c|c|c|c|c|c|}
\hline \multirow{2}{*}{ Variables } & \multicolumn{7}{|c|}{ Principal Components } \\
\hline & 1 & 2 & 3 & 4 & 5 & 6 & 7 \\
\hline $\mathrm{V}_{1}=$ Altitude $(\mathrm{msnm})$ & 0.164 & 0.115 & -0.148 & -0.320 & -0.185 & 0.616 & 0.257 \\
\hline $\begin{array}{l}\mathrm{V}_{2}=\text { Household members } \\
\text { (No.) }\end{array}$ & 0.140 & 0.219 & -0.297 & -0.110 & -0.031 & -0.479 & 0.531 \\
\hline $\begin{array}{l}\mathrm{V}_{3}=\text { Experience as an agricultural } \\
\text { producer (years) }\end{array}$ & 0.343 & -0.275 & 0.575 & 0.164 & 0.153 & 0.071 & -0.040 \\
\hline $\begin{array}{l}\mathrm{V}_{4}=\text { Age of head of household } \\
\text { (years) }\end{array}$ & 0.133 & -0.420 & 0.631 & 0.170 & 0.205 & -0.043 & 0.049 \\
\hline $\begin{array}{l}\mathrm{V}_{5}=\text { Schooling of the head of } \\
\text { household (years) }\end{array}$ & -0.006 & 0.195 & -0.540 & -0.055 & -0.171 & 0.188 & -0.316 \\
\hline $\mathrm{V}_{6}=$ Total property area $(\mathrm{ha})$ & 0.710 & -0.136 & -0.032 & 0.371 & -0.461 & -0.032 & 0.094 \\
\hline $\mathrm{V}_{7}=$ Area dedicated to agriculture (ha) & 0.304 & -0.146 & -0.094 & 0.595 & -0.552 & 0.038 & 0.176 \\
\hline $\mathrm{V}_{8}=$ Area dedicated to livestock (ha) & 0.853 & -0.118 & 0.016 & 0.032 & -0.048 & -0.093 & 0.027 \\
\hline $\begin{array}{l}\mathrm{V}_{9}=\text { Households that have irrigation } \\
\text { water }(\%)\end{array}$ & 0.222 & 0.758 & 0.478 & -0.146 & -0.127 & 0.065 & -0.022 \\
\hline $\begin{array}{l}\mathrm{V}_{10}=\text { Households with sufficient } \\
\text { irrigation water }(\%)\end{array}$ & 0.259 & 0.749 & 0.412 & -0.125 & -0.071 & 0.057 & -0.079 \\
\hline $\begin{array}{l}\mathrm{V}_{11}=\text { Households that have water } \\
\text { reservoirs (\%) }\end{array}$ & 0.228 & 0.515 & 0.320 & -0.159 & -0.270 & -0.215 & 0.056 \\
\hline $\begin{array}{l}\mathrm{V}_{12}=\text { Percentage of technology use } \\
\text { in agriculture }(\%)\end{array}$ & -0.146 & 0.522 & -0.134 & 0.402 & 0.226 & -0.048 & 0.162 \\
\hline $\begin{array}{l}\mathrm{V}_{13}=\text { Households that manage } \\
\text { pastures }(\%)\end{array}$ & 0.655 & -0.083 & -0.042 & -0.057 & 0.014 & 0.313 & -0.321 \\
\hline $\mathrm{V}_{14}=$ Cows in milk production (No.) & 0.796 & -0.072 & -0.156 & -0.270 & 0.202 & -0.176 & 0.052 \\
\hline $\mathrm{V}_{15}=$ Male bovines (No.) & 0.646 & -0.134 & 0.117 & 0.098 & -0.046 & 0.043 & 0.002 \\
\hline $\begin{array}{l}\mathrm{V}_{16}=\text { Milk production } \\
\left(1 \text { animal }^{-1} \text { day }^{-1}\right)\end{array}$ & 0.856 & -0.056 & -0.153 & -0.210 & 0.138 & 0.094 & -0.072 \\
\hline $\mathrm{V}_{17}=$ Total milk production $\left(1 \cdot\right.$ day $\left.^{-1}\right)$ & 0.759 & -0.061 & -0.134 & -0.274 & 0.262 & -0.170 & 0.123 \\
\hline $\mathrm{V}_{18}=$ Amount received as credit (US $\cdot \$$ ) & 0.139 & 0.054 & -0.319 & -0.150 & 0.041 & 0.123 & 0.207 \\
\hline $\begin{array}{l}\mathrm{V}_{19}=\text { Amount received for migration } \\
\left(\mathrm{US} \cdot \$ \cdot \mathrm{year}^{-1} \text { ) }\right.\end{array}$ & -0.055 & 0.003 & 0.148 & 0.161 & 0.289 & 0.501 & 0.602 \\
\hline $\begin{array}{l}\mathrm{V}_{20}=\text { Households that received } \\
\text { technical assistance }(\%)\end{array}$ & 0.290 & 0.481 & -0.217 & 0.430 & 0.255 & 0.107 & -0.112 \\
\hline $\begin{array}{l}\mathrm{V}_{21}=\text { Households that participated in } \\
\text { training courses }(\%)\end{array}$ & 0.283 & 0.300 & -0.219 & 0.558 & 0.393 & -0.043 & -0.164 \\
\hline
\end{tabular}

Source: Barrera et al., 2019. 
Table A4. Analysis of variance of the variables that defined the groups of agricultural production systems in Galapagos-Ecuador.

\begin{tabular}{|c|c|c|}
\hline Variables & Fc. & Sig. \\
\hline $\mathrm{V}_{1}=$ Altitude $(\mathrm{msnm})$ & 14.67 & $0.00^{* *}$ \\
\hline $\mathrm{V}_{2}=$ Household members (No.) & 12.62 & $0.00^{* *}$ \\
\hline $\mathrm{V}_{3}=$ Experience as an agricultural producer (years) & 4.41 & $0.01^{* *}$ \\
\hline $\mathrm{V}_{4}=$ Age of head of household (years) & 3.78 & $0.02^{*}$ \\
\hline$V_{5}=$ Schooling of the head of household (years) & 0.60 & $0.55 \mathrm{~ns}$ \\
\hline $\mathrm{V}_{6}=$ Total property area $(\mathrm{ha})$ & 6.51 & $0.00^{* *}$ \\
\hline $\mathrm{V}_{7}=$ Area dedicated to agriculture (ha) & 1.62 & $0.02^{*}$ \\
\hline $\mathrm{V}_{8}=$ Area dedicated to livestock (ha) & 8.61 & $0.00^{* *}$ \\
\hline $\mathrm{V}_{9}=$ Households that have irrigation water (\%) & 228.37 & $0.00^{* *}$ \\
\hline $\mathrm{V}_{10}=$ Households with sufficient irrigation water (\%) & 129.13 & $0.00^{* *}$ \\
\hline $\mathrm{V}_{11}=$ Households that have water reservoirs (\%) & 35.82 & $0.00^{* *}$ \\
\hline $\mathrm{V}_{12}=$ Percentage of technology use in agriculture (\%) & 26.63 & $0.00^{* *}$ \\
\hline $\mathrm{V}_{13}=$ Households that manage pastures (\%) & 18.47 & $0.00^{* *}$ \\
\hline $\mathrm{V}_{14}=$ Cows in milk production (No.) & 6.55 & $0.00^{* *}$ \\
\hline $\mathrm{V}_{15}=$ Male bovines (No.) & 6.10 & $0.00^{* *}$ \\
\hline $\mathrm{V}_{16}=$ Milk production $\left(1\right.$ animal ${ }^{-1}$ day $\left.^{-1}\right)$ & 12.35 & $0.00^{* *}$ \\
\hline $\mathrm{V}_{17}=$ Total milk production $\left(1 \cdot \mathrm{day}^{-1}\right)$ & 4.98 & $0.01^{* *}$ \\
\hline $\mathrm{V}_{18}=$ Amount received as credit (US.\$) & 0.27 & $0.76 \mathrm{~ns}$ \\
\hline $\mathrm{V}_{19}=$ Amount received for migration (US. $\$ \cdot$ year $^{-1}$ ) & 4.28 & $0.02^{*}$ \\
\hline $\mathrm{V}_{20}=$ Households that received technical assistance (\%) & 13.38 & $0.00^{* *}$ \\
\hline $\mathrm{V}_{21}=$ Households that participated in training courses (\%) & 12.37 & $0.00^{* *}$ \\
\hline
\end{tabular}

Source: Barrera et al., 2019. Fc. $=$ F "Fisher" calculated; Sig. ns $=$ Not statistically significant $>5 \%$; ${ }^{*}=$ Statistically Significant $>$ from $1 \%$ to $5 \%$; $* *$ Highly significant $\leq 1 \%$. 